\title{
ESTIMATION OF PHOSPHORUS EMISSIONS IN THE UPPER IGUAZU BASIN (BRAZIL) USING GIS AND THE MORE MODEL
}

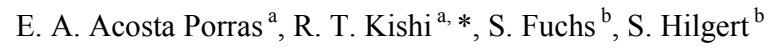 \\ ${ }^{a}$ PPGERHA/UFPR, Federal University of Paraná, 81531-990 Curitiba/PR, Brazil - (eacosta, rtkishi.dhs)@ufpr.br \\ ${ }^{\mathrm{b}}$ Institute for Water and River Basin Management, Department of Aquatic Environmental Engineering, Karlsruhe Institute of \\ Technology, Gothard-Franz-Str.3, 76131 Karlsruhe, Germany - (stephan.fuchs, stephan.hilgert)@kit.edu
}

\section{Commission VI, WG VI/4}

KEY WORDS: Phosphorus Emissions, Water Pollution, MoRE Model, Basin Management

\begin{abstract}
:
Pollution emissions into the drainage basin have direct impact on surface water quality. These emissions result from human activities that turn into pollution loads when they reach the water bodies, as point or diffuse sources. Their pollution potential depends on the characteristics and quantity of the transported materials. The estimation of pollution loads can assist decision-making in basin management. Knowledge about the potential pollution sources allows for a prioritization of pollution control policies to achieve the desired water quality. Consequently, it helps avoiding problems such as eutrophication of water bodies. The focus of the research described in this study is related to phosphorus emissions into river basins. The study area is the upper Iguazu basin that lies in the northeast region of the State of Paraná, Brazil, covering about 2,965 $\mathrm{km}^{2}$ and around 4 million inhabitants live concentrated on just $16 \%$ of its area.
\end{abstract}

The MoRE (Modeling of Regionalized Emissions) model was used to estimate phosphorus emissions. MoRE is a model that uses empirical approaches to model processes in analytical units, capable of using spatially distributed parameters, covering both, emissions from point sources as well as non-point sources. In order to model the processes, the basin was divided into 152 analytical units with an average size of $20 \mathrm{~km}^{2}$. Available data was organized in a GIS environment. Using e.g. layers of precipitation, the Digital Terrain Model from a 1:10000 scale map as well as soils and land cover, which were derived from remote sensing imagery. Further data is used, such as point pollution discharges and statistical socio-economic data. The model shows that one of the main pollution sources in the upper Iguazu basin is the domestic sewage that enters the river as point source (effluents of treatment stations) and/or as diffuse pollution, caused by failures of sanitary sewer systems or clandestine sewer discharges, accounting for about $56 \%$ of the emissions. Second significant shares of emissions come from direct runoff or groundwater, being responsible for $32 \%$ of the total emissions. Finally, agricultural erosion and industry pathways represent $12 \%$ of emissions. This study shows that MoRE is capable of producing valid emission calculation on a relatively reduced input data basis.

\footnotetext{
* Corresponding author
} 


\section{INTRODUCTION}

Sources and causes of waterbody impairments and threats should be addressed basin-wide to target the priority measures for the protection and restoration of water bodies to ensure a long-term good ecological status. Approaches describing the current state of surface water bodies under a holistic perspective are crucial to assist in management strategies and measures.

One of the most widespread problems of inland waters is eutrophication (Berlekamp et al. 2007; He et al. 2011; Chinh et al. 2011; UNESCO 2012) when surface water bodies are affected by nutrient loads. Phosphor is normally the limiting nutrient in the aquatic environment (Von Sperling 1996) in that case, its increased input will lead to unwanted proliferation of algae and macrophytes, resulting in potential ecological degradation. Therefore, it is necessary to control the causes and sources of phosphor in order to reduce inputs into water bodies. MoRE (Modeling of Regionalized Emissions) was used to calculate the current input situation of phosphorous loads in the catchment of upper Iguazu River. The MoRE system comprises approaches for the estimation of emission pathways of 14 pollutants related to point and diffuse sources on a basin scale (Fuchs et al. 2010), (Fuchs et al. 2012) The MoRE model originated as part of the German Environment Agency's demand, to develop a database and modeling application covering all German river basins aiming on an appropriate description of rivers status. It is a model designed to support decision-making processes. It has the potential to examine limits from guidelines in order to achieve good ecological status of surface water bodies.

\section{STUDY AREA}

The study area is the upper Iguazu basin, located in South Brazil, between latitudes $25^{\circ} 10^{\prime}$ and $25^{\circ} 50^{\prime}$ South and longitudes $48^{\circ} 50^{\prime}$ and $49^{\circ} 50^{\prime}$ West (Figure 1). The area extends over $2964 \mathrm{~km}^{2}$ with 27 tributaries. Within the basin, the capital of Parana state is located, with 2.934 .700 inhabitants (2010 census) in the greater area. The soil use of the basin includes highly urbanized areas $(15 \%)$, intensive agricultural activities (47\%) and a high density of industries (about 9000 industries). At the same time, a high number of surface water supply sources are present in the basin, including five reservoirs in operation and one in construction. Downstream of the investigation area further reservoirs for hydroelectric use are located at the Iguazu River.

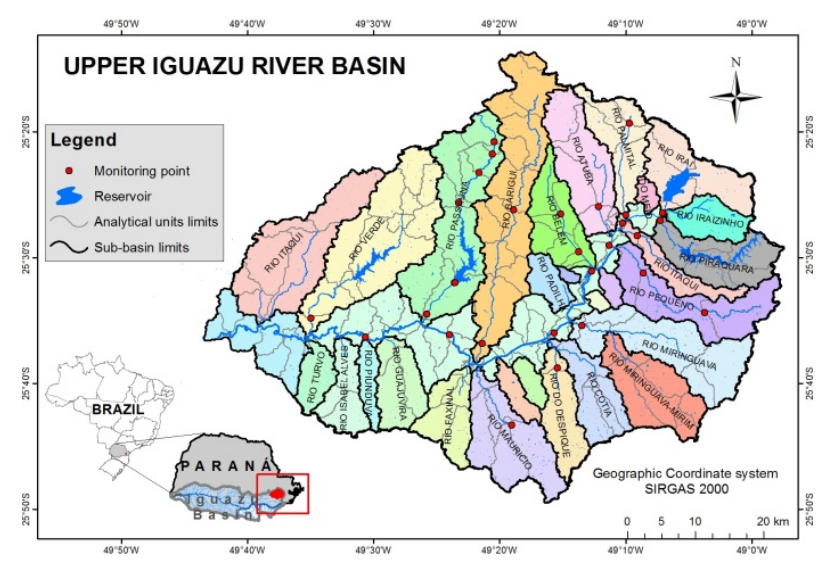

Figure 1. Upper Iguazu localization. Each colored sub-basin is separated into several Analytical Units (AU)

Consequently, the Upper Iguazu River basin is an area of high tension between water demands and deterioration processes.
This creates the urgent need to develop a proper diagnosis to define basin management plans and their future monitoring.

\section{MORE SYSTEM}

\subsection{Model construction and data}

The MoRE model for Upper Iguazu was set up by implementing observed data (see Figure 2) from various institutions (Instituto das Águas do Paraná, Embrapa, IAPAR, IBGE, IAP, ANA, Sanepar, etc.), aiming on the calculation of phosphorus emissions in 153 analytical units. Each analytical unit represents a hydrologic unit with its own characteristics, and MoRE provides the inventory of both point and diffuse sources.

Analytical units are delimitated with the hydrologic tools in ArcGIS Spatial Analyst (ESRI) using the following criteria: a 100 hectares threshold and the delineation matches the 29 flow and phosphor monitoring points (LACTEC \& FINEP, 2007; ANA, 2014).

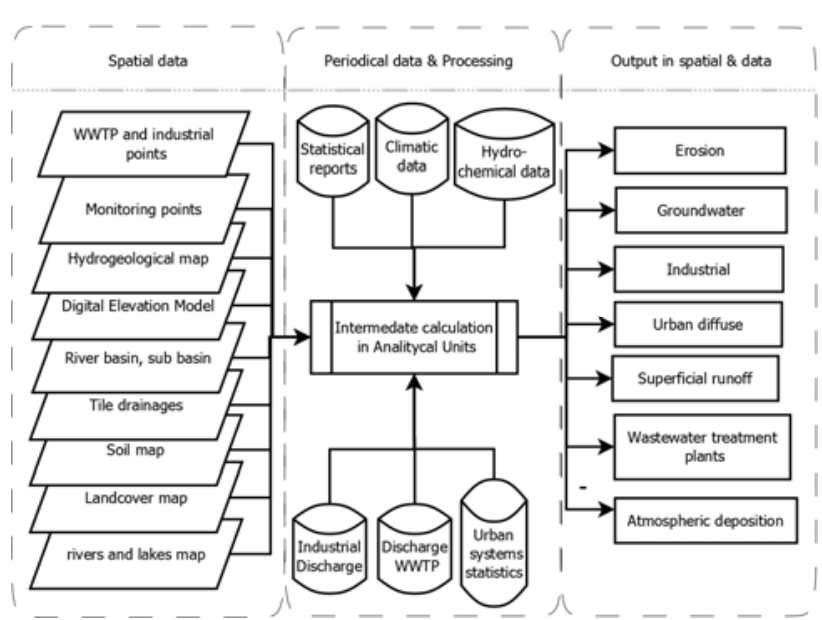

Figure 2. Basic input data is presented in the diamonds. External pre-processed data is shown as cylinders and the rectangle represents the seven relevant emission pathways.

Raw data is listed in Table 1.

Table 1. Input raw data of MoRE for Upper Iguazu Basin

\begin{tabular}{|l|l|}
\hline Information layers and attributes & Origin \\
\hline DEM - Digital Elevation Model & $\begin{array}{l}\text { Instituto das } \\
\text { Águas do Paraná }\end{array}$ \\
\hline $\begin{array}{l}\text { Land use by interpretation of digital aerial } \\
\text { photographs orthorectified (orthophotos) } \\
\text { June 2000 with scale 1: 20,000 }\end{array}$ & $\begin{array}{l}\text { Instituto das } \\
\text { Águas do Paraná }\end{array}$ \\
\hline $\begin{array}{l}\text { Soil map (1: 20,000 published by DSG and } \\
\text { IBGE) }\end{array}$ & $\begin{array}{l}\text { Embrapa, } \\
\text { IAPAR }\end{array}$ \\
\hline Geology map & $\begin{array}{l}\text { Instituto das } \\
\text { Águas do Paraná }\end{array}$ \\
\hline Phosphorus content in the soil plants: position, & $\begin{array}{l}\text { EMBRAPA; } \\
\text { IAPAR }\end{array}$ \\
\hline $\begin{array}{l}\text { Sewage treatment } \\
\text { effluents concentration }\end{array}$ & $\begin{array}{l}\text { Environmental } \\
\text { licenses - IAP }\end{array}$ \\
\hline Industrial wastewater & $\begin{array}{l}\text { Instituto das } \\
\text { Águas do Paraná }\end{array}$ \\
\hline Municipal limits & IBGE \\
\hline Census area and data & $\begin{array}{l}\text { Hidroweb } \\
\text { databank - ANA }\end{array}$ \\
\hline $\begin{array}{l}\text { Flow and water quality monitoring points } \\
\text { and data }\end{array}$ & \\
\hline
\end{tabular}


All data in this study is processed within a GIS environment as input data of MoRE, e.g. soil loss map and slope map.

The MoRE system allows for the estimation of emission pathways related to point sources (municipal wastewater treatment plants, direct industrial discharges and emissions from historic mining) and related to diffuse sources (sewer systems, surface runoff, erosion, groundwater, tile drainage, direct atmospheric deposition onto water surfaces and inland navigation).

\subsubsection{Point source estimation}

The emissions are calculated based on the volume and a measured concentration, leading to mass fluxes.

The wastewater treatment plant's (WWTP) data is obtained from the sanitation company SANEPAR, which provided averaged data for the WWTPs.

The information about industrial discharges was available only in paper form, for that was include only the flow discharge that was available by each geographic point. To accelerate the data input process the concentration of the industrial effluent in the catchment was considered to be equal to the effluent discharge requirements presented in the industry guidelines for the industries (The World Bank 1999), according to the type of industry. For this purpose, the types of industries, who are known to emit phosphor, according to the guidelines for the industries, were selected. The discharge was estimated from the water users grant registration by the Instituto das Águas do Paraná including average and maximum values.

\subsubsection{Diffuse source estimation}

The pollution sources, which are not controlled and reach the water body without treatment, are considered as diffuse sources in the model. MoRE calculates these sources using 6 modules: (1) Emissions generated as a result of erosion from agricultural areas and natural vegetation; (2) Emissions that could reach the river directly by agricultural drainage; (3) Emissions from areas of direct runoff; (4) Emissions by atmospheric deposition; (5) Amount of substances that is transported through the groundwater and (6) Uncontrolled emissions from urban areas. Urban systems in this case include diffuse rainwater drainage that carries substances into the river without any treatment and deficiencies in the network of sewage collection and treatment plants.

Total emissions by erosion (1) are based on the calculation of soil loss by the USLE (Universal Soil Loss Equation), the phosphorus content in the top soil, the sediment delivery coefficient ratio and the enrichment factor. The modules (2), (3) and (5) are estimated with the mass flow and respective concentration along the path. The atmospheric deposition (4) considers surface deposition rate average on the water surface found in literature (Migliavacca et al. 2005;Anderson \& Downing 2006; Zhai et al. 2009; Shen et al. 2013). Module (6) generates an estimative of phosphorus load that can reach the water body in an uncontrolled manner, based on population numbers and per capita contributions, as well as the overflow from combined sewer systems under high rainfall situations.

\subsection{Verification}

In the verification step, the discharge and phosphorus emissions were set in relation to data from 29 monitoring stations in the upper Iguazu river basin. The observed Phosphorus loads were calculated through the discharge and phosphorus concentration.
The phosphorus concentrations in the monitoring stations were collected every 15 days and afterwards the mean value was calculated for the use in the model

The accuracy between simulated and observed data was computed as follows:

\subsubsection{Nash-Sutcliffe efficiency coefficient:}

$$
E_{N S}=1-\frac{\sum_{i=1}^{n}\left(O_{i}-S_{i}\right)^{2}}{\sum_{i=1}^{n}\left(O_{i}-\bar{O}\right)^{2}}
$$

Where $O_{i}$ is the $i^{\text {th }}$ observation for the constituent being evaluated, $S_{i}$ is the $i^{t h}$ simulated value for the constituent being evaluated, $\bar{O}$ is the mean of observed data for the constituent being evaluated, and $n$ is the total number of observations. T is the ith observation he Nash-Sutcliffe efficiency coefficient $(E)$ can vary from $-\infty$ to 1 . Values $<0.5$ indicate unsatisfactory while values near to 1 have a very good performance (Moriasi et al. 2007; Krause et al. 2005).

\subsubsection{Percent bias (PBIAS):}

$$
\text { PBIAS }=\left[\frac{\sum_{i=1}^{n}\left(O_{i}-S_{i}\right) * 100}{\sum_{i=1}^{n}\left(O_{i}\right)}\right]
$$

Where $O$ are observed and $\mathrm{S}$ simulated values, bias shows the average tendency of the simulated data to be larger or smaller than observed data. The optimal value is 0.0 , low values indicate accurate, positive values indicate underestimation and negative values indicate model overestimation (qtd. in Gupta et al., 1999; Moriasi et al. 2007).

\subsubsection{Coefficient of determination $\left(\mathrm{r}^{2}\right)$ :}

$$
r^{2}=\frac{\left[\sum_{i=1}^{n}\left(O_{i}-\bar{O}\right)\left(S_{i}-\bar{S}\right)\right]^{2}}{\sum_{i=1}\left(O_{i}-\bar{O}\right)^{2} \sum_{i=1}\left(S_{i}-\bar{S}\right)^{2}}
$$

Likewise the PBIAS, $O$ are observed and $\mathrm{S}$ simulated values. The range of $r^{2}$ describes with values between 0 and 1 how much the observed dispersion is explained by the simulation (Krause et al. 2005).

Root mean square error (RMS-error):

$$
R M S E=\sqrt{\frac{1}{n} \sum_{i=1}^{n}\left(S_{i}-O_{i}\right)^{2}}
$$

Where $O$ are observed and S simulated values. The lower the RMSE the better the model efficiency (Boyle et al. 2000; Chai et al. 2014; Hengl 2009).

\section{RESULTS \& DISCUSSION}

\subsection{Estimation of phosphorus emissions}

The specific phosphorus emissions calculated by MoRE are shown in Figure 3, which represents the sum of all point emissions and the diffuse pathways for every analytical unit. Figure 3 visualizes the emissions per $\mathrm{km}^{2}$ in the upper Iguazu basin on the AU-resolution scale. It resembles helpful information for the purpose of taking corrective or protective measures in the basin to control water quality. The estimate denotes a high incidence of phosphorus by direct entry, pointing out that the Padilha, Belém, Atuba and Barigui river basins, which are urban watersheds, are those with the highest export 
coefficients in the Upper Iguazu basin. They account for 2,818 $\mathrm{kg} / \mathrm{km}^{2}, \quad 1,550 \mathrm{~kg} / \mathrm{km}^{2}, \quad 893 \mathrm{~kg} / \mathrm{km}^{2}$ and $560 \mathrm{~kg} / \mathrm{km}^{2}$, respectively. The estimate shows that the entire catchment area generates approximately 1,540 tons of phosphorus per year.

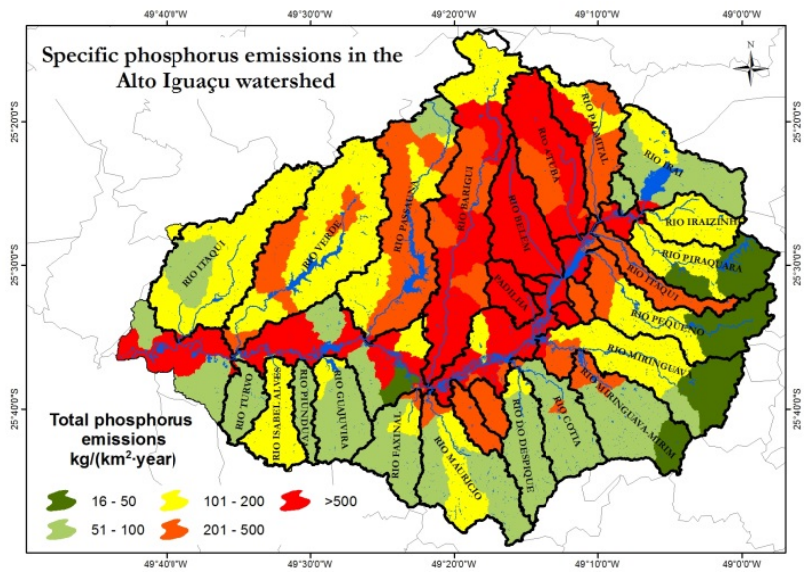

Figure 3. Specific phosphorus by sub-watershed $\left(\mathrm{kg} / \mathrm{km}^{2} \cdot\right.$ year)

Figure 4 displays the results in each Iguazu tributary basin according to the pathways and the respective total emission in the secondary axe. The basins were placed in descending order of emission in the graph, from left to right. The Barigui, Belém and Padilha river basins show the highest contribution of phosphorus emission to the Iguazu River, WWTPs being the main source. This source represents about $28 \%$ of phosphorus emitted per year to the water bodies in the basin.

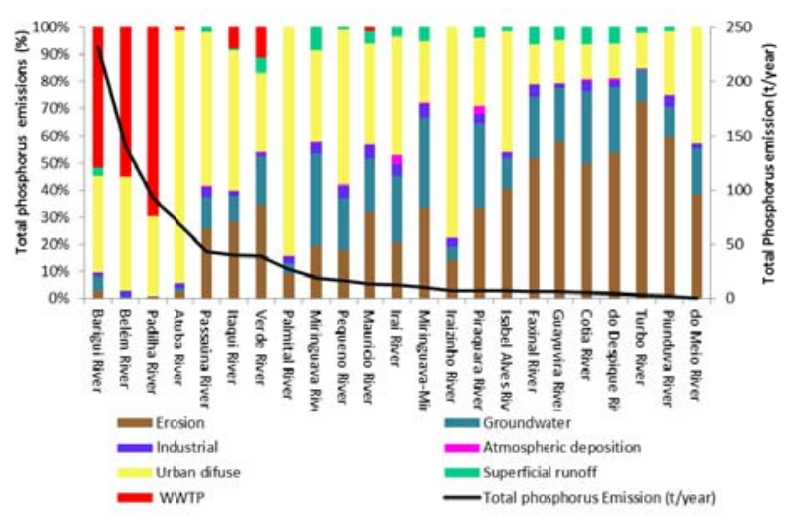

Figure 4. Phosphorus emissions (ton/year) and percentage path

Another significant source, with 27 percent (420 ton/year), are the diffuse emissions from urban areas. A major share of these emissions is generated by inhabitants and is not treated in wastewater treatment plants, but with septic tanks or is directly discharged into the river.

There is an increase of the relative contribution of phosphorus by erosion in the rural basins of the study area, in contrast to the urban basins in the Upper Iguazu. However, quantitatively, the contribution by erosion is small in all the Upper Iguazu (only a total of 102 ton/year), since the rural basins load values are significantly smaller those found as in urban basins (see the solid line in Figure 4).

\subsection{Verification of MoRE model with observed values}

Figure 5 and Figure 6 show the comparison of simulated water flow and phosphorus loads with 29 data sets of observed data. The solid line is a $45^{\circ}$ line and the dotted lines mark the region where the simulated values vary up to $30 \%$ from the observed ones .

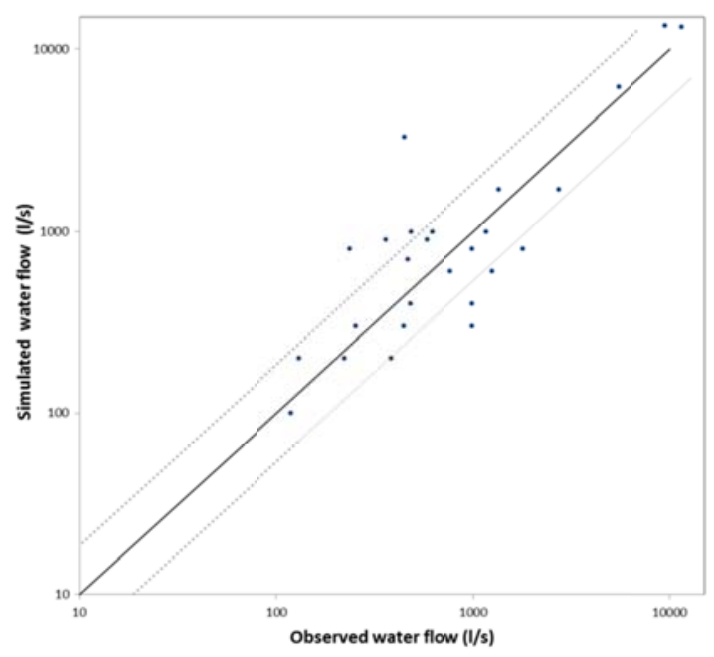

Figure 5. Observed and simulated discharge

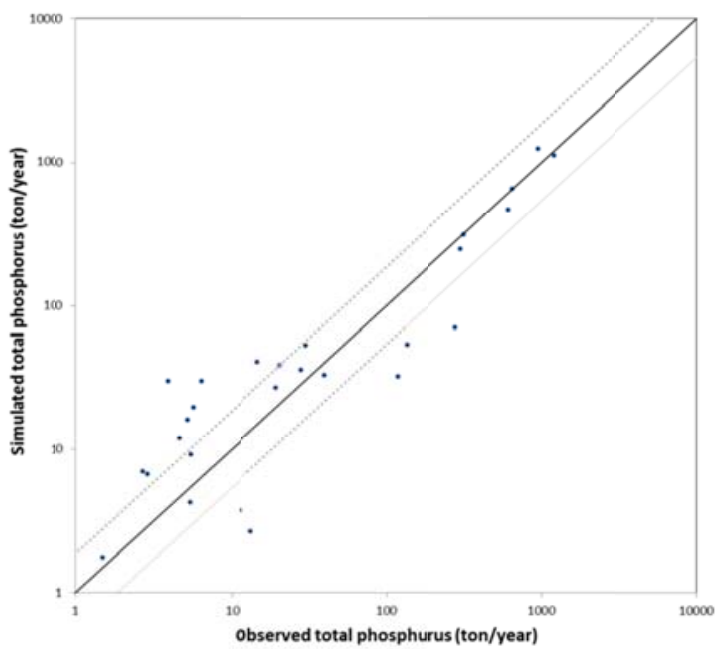

Figure 6. Observed and simulated total phosphorus

The efficiency between simulated and observed data were calculated with Nash-Sutcliffe, bias, coefficient of determination $\left(\mathrm{R}^{2}\right)$ and root mean square error (RMSE), which are presented in Table 2 .

Table 2. Discharge and total Phosphorus emissions efficiency statistics

\begin{tabular}{lllll}
\hline & Nash & BIAS & $\mathrm{R}^{2}$ & RMSE \\
\hline Water Flow (1/s) & 0.90 & 13.4 & 0.94 & 1.07 \\
P-Emissions (ton/year) & 0.93 & 5.0 & 0.94 & 79.4 \\
\hline
\end{tabular}


The Nash-Sutcliffe coefficients are close to one for both analyzed variables. That means that the predictive accuracy of MoRE in this case is excellent.

The coefficient $\mathrm{R}^{2}$ close to one shows a good correlation between the observed and modeled data. The positive values of PBIAS considering all data (Table 2) indicate that MoRE produces a slight underestimation bias. However, if the data is divided into two groups with a threshold of 50 ton/year, loads smaller than 50 ton/year has a negative bias $(-80)$ and values larger than 50 ton/year have a positive bias (8.5).

The difference between the simulated and observed values was expected, since the model calculates emissions and the observed data are loads in the river. The model does not consider transport and retention in the watercourse, but only the release of the substance into the water bodies of the basin. Another aspect is related to the water quality monitoring data. Sampling is discrete, every 15 days, and does not allow computing an accurate average, since water quality has strong variations along time. There is also the problem that, sometimes, flow measurements were not available for the same time when the water quality monitoring was performed. Data were also collected during low flow events and there are few data in high intensity rainfall events.

\section{CONCLUSIONS}

MoRE shows to be a support tool for watershed management that allows a holistic vision of emission in the interest area. This model offers a detailed view of all activities that may export some contaminant to the river. It gives necessary information to take measures to control the causes of the problems. Looking at this scenario, decision makers have an idea of what is needed to improve phosphorus retention and sanitary systems.

In the relevant basin water quality data and further information is scarce. Since data is always the constraining factor for modeling a model should be able to produce good results also with limited available data. In this study, industry-related data quality is low and only the largest WWTPs are considered, however the used MoRE implementation in Upper Iguazu is a starting point to a first analysis and even restricted data shows to be enough to serve this purpose. It can be substituted over time as better information becomes available, yet the presented study shows high already existing potential.

To obtain more accurate results and verify the efficiency of implemented measures more and rational investments in monitoring programs are necessary.

The watershed planning process is geographically defined, and the issues about water resources management always require geographic aspects, data and vision.

\section{ACKNOWLEDGEMENTS}

Organization of American States e Coimbra Group, Programa de Pós Graduação em Engenharia de Recursos Hídricos e Ambiental da Universidade Federal do Paraná, The Karlsruhe Institute of Technology (KIT), Projeto Integra, Instituto das Águas do Paraná, Embrapa, IAPAR, IBGE, IAP, ANA, Sanepar.

\section{REFERENCES}

ANA, 2014. Hidroweb: Sistemas de informações hidrológicas. Available at: http://hidroweb.ana.gov.br/.

Anderson, K. A. \& Downing, J. A., 2006. DRY AND WET ATMOSPHERIC DEPOSITION OF NITROGEN , PHOSPHORUS AND SILICON IN AN AGRICULTURAL REGION. Water, Air, and Soil Pollution, 176(1-4), pp.351-374. Available at: http://link.springer.com/10.1007/s11270-006-9172-4 [Accessed August 20, 2013].

Berlekamp, J. et al., 2007. Integration of MONERIS and GREAT-ER in the decision support system for the German Elbe river basin. Environmental Modelling \& Software, 22(2), pp.239-247.

Boyle, D. P., Grupta, H. V. \& Sorooshian, S., 2000. Toward improved calibration of hydrologic models: Combining the strengths of manual and automatic methods. Water Resources Management, 36, pp.3663-3674. Available at: http://onlinelibrary.wiley.com/doi/10.1029/2000WR9002 07/epdf.

Chai, T., Draxler, R.R. \& Prediction, C., 2014. Root mean square error ( RMSE ) or mean absolute error ( MAE )? Arguments against avoiding RMSE in the literature. Geoscientific Model Development, 7(2005), pp.12471250. Available at: http://www.geosci-modeldev.net/7/1247/2014/gmd-7-1247-2014.pdf.

Chinh, L. et al., 2011. Simulation of rainfall runoff and pollutant load for Chikugo River basin in Japan using a GIS-based distributed parameter model. Paddy and Water Environment, 11(1-4), pp.97-112.

Fuchs, S. et al., 2010. Calculation of Emissions into Rivers in Germany using the MONERIS Model: Nutrients, heavy metals and polycyclic aromatic hydrocarbons, DessauRoßlau Germany: Federal Environment Agency (Umweltbundesamt). Available at: http://www.uba.de/uba-info-medien-e/4018.html.

Fuchs, S. et al., 2012. Modeling of Regionalized Emissions (MoRE). Available at: http://isww.iwg.kit.edu/MoRE.php.

He, J. et al., 2011. Dry and wet atmospheric deposition of nitrogen and phosphorus in Singapore. Atmospheric Environment, 45(16), pp.2760-2768.

Hengl, T., 2009. A Practical Guide to Geostatistical Mapping 2nd ed. Uva.nl, ed., Amsterdam.

Krause, P., Boyle, D.P. \& Base, F., 2005. Comparison of different efficiency criteria for hydrological model assessment. Advances in Geosciences, 5, pp.89-97. Available at: http://www.advgeosci.net/5/89/2005/adgeo-5-89-2005.pdf.

LACTEC \& FINEP, 2007. Desenvolvimento de metodología para enquadramento de corpos de água da bacia Alto Iguaçu, Curitiba - Paraná. Available at: //www.recursoshidricos.pr.gov.br/arquivos/File/COALIA $\mathrm{R} /$ Comite/3a reuniao ordinaria/apres_lactec_metodologia_enquadramento_coal iar.pdf.

Migliavacca, D. et al., 2005. Evaluation of the atmospheric deposition in an urban region in south brazil. Water, Air, and Soil Pollution, 167, pp.91-110.

Moriasi, D.N. et al., 2007. Model evaluation guidelines for systematic quantification of accuracy in watershed simulations. American Society of Agricultural and Biological Engineers, 50(3), pp.885-900.

Shen, J. et al., 2013. Atmospheric dry and wet nitrogen deposition on three contrasting land use types of an agricultural catchment in subtropical central China. 
Atmospheric Environment, 67, pp.415-424. Available at: http://linkinghub.elsevier.com/retrieve/pii/S13522310120 10692 [Accessed September 15, 2013].

Von Sperling, M., 1996. Introdução à qualidade das águas e ao tratamento de esgotos. $2^{\circ}$ ed. D. de E. S. e A. -UFMG, ed., Belo Horizonte - MG.

The World Bank, 1999. Pollution Prevention and Abatement Handbook 1998 - Toward Cle. T. W. Bank, ed., Washington.

UNESCO, 2012. Managing Water under Uncertainty and Risk: The United Nations World Water Development Report 4,
Paris, France. Available at: http://unesdoc.unesco.org/images/0021/002156/215644e. pdf.

Zhai, S., Yang, L. \& Hu, W., 2009. Observations of atmospheric nitrogen and phosphorus deposition during the period of algal bloom formation in northern Lake Taihu, China. Environmental management, 44(3), pp. $542-51$. 